\rangle$\rangle\rangle\rangle\rangle$ 巻頭言 $\langle\langle\langle\langle\langle$

\title{
Change or Die
}

EjSAG

栗木 隆

江崎グリコ(侏) 取締役＼cjkstart常務執行役員 研究部門統括 研究本部長

比較的古い言葉であると思うが，多くの企業の経営者が最近よく使うようになった衝撃的な言葉である。

“Trick or Treat”はハロウィーン, “Publish or Perish”は科学者の掟ではあるが, それより響きはずっと重

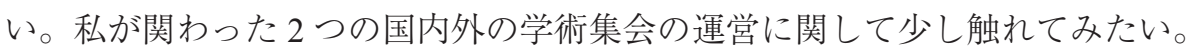

日本のある学術集会の運営を話し合う中で「この分野の基礎科学の研究者が減少しているせいか，今年の 企画内容を見ると，まるで別の学会のようだ。」「この会のアイデンテティが薄れていかないようにする工夫 が必要と思う。という意見があった。自分が育ちまた育ててきた研究分野に対する郷愁は誰にでもあり， 時には大切にしなければならないものでもある。ただ, その会の発展をミッションとする立場から, 私は申 し上げた。「この分野で魅力的な基礎研究を発表できる人が少なくなったこと, 新たな産業を生むほどの本 当に産業界に貢献できる研究を推進できる人が少なくなったことが理由である。この会のアイデンテティを 守るということはこの会が世の中の変化の中で消えるリスクを含んでいる。世の中の変化を読んで，取り上 げる分野を斬新に変えていかなければならない。」若い研究者の感性は大切である。企画を任された彼らは 見事にその会を再び魅力あるものにつくり変えてくれた。

もう1つは欧州を中心としたある国際会議の運営委員会での話。その国際会議では招待講演ないし口頭発 表した人はある journal (かつては出版本であった) に報文ないしは総説を書くことが義務であった。前回の 会議の後に，論文の集まりが悪く，これをどうしようかということになった。「報文あるいは総説を投稿す る義務を無くそう。」という意見に私は同意するとともに述べた。「この分野に対する科学者の興味が低下し てきているのを私は感じている。しかし，私たち運営委員はこの国際会議で参加者の興味をそそる話題や概 念を導入してこの低下傾向を変えることができると思う。実際，前回，私が座長をしたセッションは新たな 取り組みが多く，皆さんの分野違いであったかも知れないが，最先端の進んだ研究分野である。学術界だけ でなく産業界にも大きな興味となる, 最先端かつ実用的な研究を紹介したい。」この提案に多くの運営委員 が賛成してくれた。この国際会議も変わるであろう。余談を言うと，1999年か 2001 年のこの会議で名教科 書「コーン・スタンプ」の著者の 1 人であり，RNA polymerase などの分野の巨人である Roy H. Doi 教授と 会ったことがある。彼は，この会にポスター発表をしに来ていた。私が「あなたのような著名な方が，なぜ ポスター発表など…と言うと「私は少し前から cellulosomeの研究を始めてね。と微笑まれた。Doi 教授 は見事に changeされ，間もなくまたこの分野で巨人になられた。

「死に絶えたくなければ変われ。」学会にもこれが必用な時代である。 